\title{
COHABITATION WORLDWIDE TODAY
}

\section{By Margaret Ryznar* \& Anna Stępień-Sporek**}

\begin{abstract}
Despite the increase in cohabitation around the world, legal responses to it remain limited, particularly in the last several years. Yet, there are universal issues at the end of a cohabitation, particularly related to property division. This article will survey the recent legal developments on the property consequences of cohabitation in both the United States and Poland, drawing on comparative lessons to suggest future developments in this area of law.
\end{abstract}

\section{INTRODUCTION}

Around the world, cohabitation has been on the rise for decades with many millions of couples living together outside of marriage. ${ }^{1}$

\footnotetext{
* Professor of Law, Indiana University McKinney School of Law. The authors would like to thank Jessica Dickinson and Ben Keele for excellent research assistance.

** Attorney-at-law, partner at Stępień-Sporek, Pawelski, Stoppa Spółka Partnerska Kancelaria Radców Prawnych I Adwokatów.

1. Patrick Parkinson, Can Marriage Survive Secularization?, 2016 U. ILL. L. REV. 1749, 1753-54 (2016). The author states as follows:

Legal marriage, which was once the only accepted context for sexual relations and the nurture of children in western countries, has long ceased to be central to people's sexual or reproductive lives in many parts of the world.
}

Marriage remains the most common form of couple relationship within Western and Northern Europe, but the gap between marriage and cohabitation as a family form is narrowing. For example, figures from 2006 show that in France, twentysix percent of adults in the eighteen to forty-nine age range were cohabiting, while thirty-nine percent were married. In Sweden, twenty-five percent were cohabiting and thirty-seven percent were married. In the United Kingdom, in 2001, twenty-two percent of adults aged between twenty and thirty-four were cohabiting, while thirty-two percent were married.

In the United States, marriage is increasingly stratified by reference to educational level. The percentage of adults aged twenty-five to sixty with four years of high school education but no college education, and who were in first marriages, fell from seventy-three percent in the 1970 s to forty-five percent in the 2000 s. There was also a twenty-eight percent decline in first marriages among the least educated adults over this same time period. While rates of marriage have declined for people of all educational levels, the rate of decline 
The United States is no exception: single people recently outnumbered married people for the first time in history. ${ }^{2}$ Many Americans are cohabitating instead of marrying. ${ }^{3}$ For example, marital households recently comprised less than half of all households in the United States, while almost $6 \%$ of households were opposite-sex, unmarried partners. ${ }^{4}$ Over 7 million opposite-sex couples cohabitated in $2010,{ }^{5}$ a dramatic increase from the 523,000 cohabitating couples in $1970 .{ }^{6}$ Between 2000 and 2010 alone, there was a $41 \%$ increase in unmarried couple households. ${ }^{7}$ Unthinkable and even criminal for much of history, ${ }^{8}$ cohabitation has become a transition to marriage or even a substitute for it. ${ }^{9}$

In Poland, the trend is similar. According to the European Social Survey, cohabitants comprised $4.5 \%$ of all unions in 2006 , an

Id. has been least among college-educated people.

2. See, e.g., REBecCa TRAISTER, ALl THE SINGLE LADIES: UNMARRIED WOMEN AND THE RISE OF AN INDEPENDENT NATION 5 (2016).

3. Parkinson, supra note 1 , at 1753 .

4. DaPhNe LofQuist et AL., U.S. Census BuREau, households AND Famlies: 20105 (2012), https://www.census.gov/prod/cen2010/briefs/c2010br-14.pdf [https://perma.cc/D6W8-H5SN]; Katharine Silbaugh, Distinguishing Households from Families, 43 FORDHAM URB. L.J. 1071, 1074 (2016) ("We are not a marriage population predominantly in practice, and children are not predominantly raised for 18 years by their two parents in a common household."); see also Tonya $\mathrm{L}$. Brito, Complex Kinship Networks in Fragile Families, 85 FordhaM L. REV. 2567, 2569 (2017) (reviewing the "dramatic changes to the American family that have occurred over the past half century"); Jessica R. Feinberg, The Survival of Nonmarital Relationship Statuses in the Same-Sex Marriage Era: A Proposal, 87 TEMP. L. REV. 47, 62-63 (2014).

5. LOFQUIST ET AL., supra note 4, at 3; see also Anna Steppień-Sporek \& Margaret Ryznar, The Consequences of Cohabitation, 50 U.S.F. L. REV. 75, 77 (2016) [hereinafter Consequences of Cohabitation].

6. Katherine C. Gordon, Note, The Necessity and Enforcement of Cohabitation Agreements: When Strings Will Attach and How to Prevent Them-A State Survey, 37 BRANDEIS L.J. 245, 245 (1998).

7. Lawrence W. Waggoner, With Marriage on the Decline and Cohabitation on the Rise, What About Marital Rights for Unmarried Partners?, 41 AM. C. TR. \& EsT. Couns. L.J. 49, 55 (2015).

8. Margaret M. Mahoney, Forces Shaping the Law of Cohabitation for Opposite Sex Couples, 7 J.L. \& FAM. STUD. 135, 141 (2005) (reviewing the historic criminalization of unmarried cohabitation).

9. Margaret F. Brinig \& Steven L. Nock, Marry Me, Bill: Should Cohabitation be the (Legal) Default Option?, 64 LA. L. REV. 403, 403 (2004) ("[I]ncreasingly cohabitation is being proposed not as a testing ground for marriage, but as a functional substitute for it. The trend in family law and scholarship in Europe and Canada is to treat married and cohabiting couples similarly, or even identically."); see also id. at 404 ("In [the United States], the American Law Institute [ALI] recently proposed that, at least when it comes to the law of dissolution, couples who have been living together for a substantial period of time should be treated the same as married couples."). But $c f$. Courtney G. Joslin, Discrimination In and Out of Marriage, 98 B.U. L. REV. 1, 3 (2018) (noting that cohabitation is more common among certain socioeconomic groups in the United States). 
increase from previous years. ${ }^{10}$ As outlined by Kathleen Kiernan, the official statistics show that cohabitation is still in the first stage of diffusion: ${ }^{11}$ rare and thus treated as an unusual type of relationship. ${ }^{12}$ The real data, however, may differ from the official data because some people hide their cohabitation for reasons such as societal disapproval. ${ }^{13}$ Indeed, the high number of children born outside of marriage suggests that cohabitation is more common. ${ }^{14}$

Couples choose to cohabitate instead of marry for various reasons, such as insufficient finances, ${ }^{15}$ avoidance of the cultural and legal implications of marriage, ${ }^{16}$ or simply the lack of desire to get married. ${ }^{17}$ Many cohabitations are temporary because cohabitants

10. Anna Matysiak, Is Poland Really 'Immune' to the Spread of Cohabitation? 2 (Max Planck Inst. for Demographic Research, Working Paper No. 2009-12, 2009), https://www.demogr.mpg.de/papers/working/wp-2009-012.pdf [https://perma.cc/7RG9-27ZE].

11. Kathleen Kiernan, Cohabitation in Western Europe: Trends, Issues and Implications, in JUST LIVING TOGETHER: IMPLICATIONS OF COHABITATION ON FAMILIES, CHILDREN AND SOCIAL POLICY 3, 4 (Alan Booth \& Ann C. Crouter eds., 2002); see also Monika Mynarska et al., Free to Stay, Free to Leave: Insights from Poland into the Meaning of Cohabitation, 31 DEMOGRAPHIC RESEARCH 1107, 1113 (2014).

12. Monika Mynarska \& Anna Matysiak, Diffusion of Cohabitation in Poland 15 (Inst. of Statistics and Demography Warsaw Sch. of Econ., Working Paper No. 3, 2010), http://kolegia.sgh.waw.pl/pl/KAE/struktura/ISiD/publikacje/Documents/Working_Paper/ISID_WP_3_2 010.pdf [https://perma.cc/F7HN-NJZW].

13. Id. at 11 .

14. Joanna Stańczak et al., Marriages and Births in Poland, EUROSTAT, http://ec.europa.eu/eurostat/statistics-explained/index.php/Marriages_and_births_in_Poland [https://perma.cc/5S6U-N785] (last visited Sept. 20, 2018).

15. Cynthia Grant Bowman, Social Science and Legal Policy: The Case of Heterosexual Cohabitation, 9 J.L. \& FAM. STUD. 1, 11 (2007). The author states:

Qualitative research reveals that marriage, although much revered in lower-income communities, is seen by many as appropriate only when a couple's economic situation is secure, a situation that may not happen quickly for some groups, if ever. Interviews with working- and lower-middle-class cohabitants suggest that they believe marriage should not occur until financial stability has been reached, including not only the resources for a large wedding but perhaps also for home ownership.

Id; see also Spencer Rand, The Real Marriage Penalty: How Welfare Law Discourages Marriage Despite Public Policy Statements to the Contrary-And What Can Be Done About It, 18 U.D.C. L. REV. 93, 93 (2015) ("Couples regularly complain about marriage penalties, discovering that the tax consequences of marrying make the cost of marriage prohibitive.").

16. Consequences of Cohabitation, supra note 5 , at 75 .

17. Gordon, supra note 6 , at 245. 
often eventually separate or marry ${ }^{18}$ According to one study, only $10 \%$ of cohabitants are still cohabitating after five years. ${ }^{19}$

For some couples, cohabitation is a transitory step or a testing period before marriage. However, the increase in divorces with major financial consequences, especially in Poland, may make people hesitate before formalizing their relationships. ${ }^{20}$ In other words, the negative consequences associated with divorce may be leading to a decrease in marriage. ${ }^{21}$

The increase in cohabitation cases has prompted courts to address the legal issues related to cohabitation, ${ }^{22}$ most of which concern children and the division of property. Although parents are responsible for their children regardless of whether they were ever married, ${ }^{23}$ property division between cohabitants is more gray. ${ }^{24}$ This article analyzes the recent legal developments on the property consequences of cohabitation in both the United States and Poland, drawing on comparative lessons to suggest future developments in this area of law.

18. Waggoner, supra note 7, at 64-65.

19. Marsha Garrison, Nonmarital Cohabitation: Social Revolution and Legal Regulation, 42 FAM L.Q. 309,322 (2008). However, "approximately $60 \%$ of all U.S. cohabitants and $70 \%$ of those in a first, premarital cohabitation marry within five years." $I d$.

20. Mynarska et al., supra note 11 , at 1125 .

21. Steven K. Berenson, Should Cohabitation Matter in Family Law?, 13 J.L. \& FAM. STUD. 289, 315 (2011) (noting some cohabitants avoid marriage to avoid property consequences)

22. Deborah A. Widiss, Intimate Liberties and Antidiscrimination Law, 97 B.U. L. REV. 2083, 2119 (2017). For example:

As sexual mores around cohabitation and non-marital intimacy changed, increasing numbers of (mostly different-sex) unmarried couples sought to rent apartments or houses. During the $1980 \mathrm{~s}$ and $1990 \mathrm{~s}$, there were numerous lawsuits brought across the country by couples who were refused tenancy by Id. landlords who disapproved of their choice to live together without being married.

23. Doe v. Hancock Cty. Bd. of Health, 436 N.E.2d 791, 793 (Ind. 1982) ("[U]nmarried parents have the same obligations and duties to their child as do married parents ...."); see also Leslie I. JenningsLax \& Louise T. Truax, Co-Parenting Agreements Between Unmarried Cohabitants, 50 FAM. L.Q. 349, 361 (2016) (discussing parenting agreements between cohabitants). See generally CTRS. FOR DISEASE CONTROL AND PREVENTION, UNMARRIED CHILDBEARING, http:/www.cdc.gov/nchs/fastats/unmarriedchildbearing.htm [https://perma.cc/FRT2-TF69] (last visited Feb. 20, 2017) (noting that in 2016, more than $40 \%$ of births were to single women).

24. See Berenson, supra note 21 , at 295. 


\section{Cohabitation Developments in the United States}

Recently, there have been a few legal developments on cohabitation in the United States, but they are best understood within the context of the greater framework on cohabitation, which emerged in the 1970 s through the early cases establishing the two approaches to cohabitation contracts, which are the primary ways to protect cohabitants.

The majority approach is that contracts between cohabitants are enforceable regarding the terms of their separation. ${ }^{25}$ Scholars have taken this as evidence of the shift from status to contract in family law. ${ }^{26}$ The minority approach does not recognize such contracts. ${ }^{27}$

\section{A. Legal Framework on Cohabitation}

The law on cohabitation has a very short history in the United States. Outside of common law marriage, cohabitants had few rights until notable case law developed in the $1970 \mathrm{~s} .{ }^{28}$ Marvin v. Marvin in California established the majority approach on cohabitation in the United States. $^{29}$

In Marvin, Michelle and Lee lived together for seven years without getting married, and Michelle took his last name. ${ }^{30}$ Michelle alleged

25. See infra Part 1.A.

26. Jill Elaine Hasday, The Canon of Family Law, 57 STAN. L. REV. 825, 835-36 (2004). Scholars describing the current contractualization of family law... cite the availability of no-fault divorce, the enforceability of prenuptial agreements about property distribution, and the enforceability of agreements between nonmarital partners....

... But the status-to-contract story overstates the changes that have occurred in family law over time. It obscures the substantial evidence that supports a counter-narrative that could be told about family law, but is not: the story of the persistence of status rules denying individuals choice about the structure of their relationships.

Id.

27. See infra Part I.A.

28. Cynthia Grant Bowman, A Feminist Proposal to Bring Back Common Law Marriage, 75 OR. L. REV. 709, 712 (1996) (outlining common law marriage, which is recognized only in a few states today and requires capacity, agreement, cohabitation, and holding oneself out as married). Common law marriage and religious cohabitation are beyond the scope of this article.

29. Marvin v. Marvin, 557 P.2d 106, 113 (Cal. 1976).

30. Id. at 110 . 
that Lee had promised to support her throughout her life in exchange for her work as a companion, homemaker, housekeeper, and cook. ${ }^{31}$ She argued that because of this oral agreement, she surrendered her career as an entertainer to devote herself fulltime to the household. ${ }^{32}$ Michelle asserted that this oral contract should be enforced, entitling her to support payments and to half the property that the couple had acquired during the relationship-including motion picture rights worth more than $\$ 1$ million - even though the property was all in Lee's name. ${ }^{33}$

If Michelle had been a wife rather than a cohabitant, she would have enjoyed rights to the property acquired during the marriage under divorce law. ${ }^{34}$ At the time Michelle brought her lawsuit, public policy aimed to discourage cohabitation by withholding remedies for cohabitants. ${ }^{35}$

The California trial court in Marvin v. Marvin granted a judgment on the pleadings for Lee, resulting in his receipt of all of the couple's property upon the break-up of the relationship. ${ }^{36}$ The California Court of Appeals affirmed in Lee's favor. ${ }^{37}$ The California Supreme Court, however, reversed in favor of Michelle, holding that a contract between unmarried partners should be enforced except to the extent that it explicitly rests on the consideration of meretricious sexual services. ${ }^{38}$

It has long been public policy in the United States to disallow payment for sexual services, but in Marvin, the California Supreme Court made the distinction between contracts based on domestic services and those based on sexual relations. ${ }^{39}$ The court thus held

\footnotetext{
31. Id.

32. Id

33. Id.

34. Rebecca Aviel, Family Law and the New Access to Justice, 86 FORDHAM L. REV. 2279, 2283

35. Marvin, 557 P.2d at 112.

36. Id. at 110 .

37. Id.

38. Id.

39. Courtney Megan Cahill, Reproduction Reconceived, 101 MINN. L. REV. 617, 694 (2016)
} (2018). 
that the terms of the contract as alleged by Michelle relied on lawful consideration, providing a basis for declaratory relief in her favor. ${ }^{40}$

Several earlier decisions from the California courts made a similar distinction. ${ }^{41}$ Marvin followed these decisions, citing the principle that cohabitants should be able to contract with one another regarding property. ${ }^{42}$

Marvin is a watershed case because the California Supreme Court concluded that if cohabitants lacked an express contract, the court should inquire into the conduct of the parties to determine whether it demonstrated an implied contract, agreement of partnership or joint venture, or some other tacit understanding between the parties. ${ }^{43}$ To resolve these types of cases, the Marvin court allowed the use of the doctrine of quantum meruit, as well as constructive and resulting trusts. ${ }^{44}$ Given the public policy against cohabitation at the time, the Marvin decision was important. ${ }^{45}$

To reach its decision, the California Supreme Court in Marvin rejected several reasons previously used to deny relief to cohabitants. First, the court refused to deny relief as punishment for a nonmarital relationship because it necessarily rewards the other party. ${ }^{46}$ Second, the court noted that reasonable expectations and equitable considerations can exist outside of marriage. ${ }^{47}$ Third, the court rejected the idea that services provided with no express contract would be a gift. ${ }^{48}$ Finally, the court rejected the notion that an equitable distribution of property between nonmarital partners would discourage marriage. ${ }^{49}$ The court noted that, if anything, the inequitable distribution that would occur if no implied contract was

40. Marvin, 557 P.2d at 116.

41. Id. at 112 .

42. Id. at 116 .

43. Id. at 122 .

44. Id.

45. Deborah Zalesne, The Contractual Family: The Role of the Market in Shaping Family Formations and Rights, 36 CARDOZO L. REV. 1027, 1038-39 n.36 (2015).

46. Marvin, 557 P.2d at 121.

47. Id.

48. Id.

49. Id. at 122 . 
recognized would discourage marriage since it would be much to the advantage of the property holder to remain unmarried. ${ }^{50}$

Family law generally falls within the domain of the states, ${ }^{51}$ and after the Marvin decision, most states followed California's lead, illustrating a shift in cultural attitudes and public policy. ${ }^{52} \mathrm{~A}$ minority of states decided not to follow Marvin for public policy reasons, with Hewitt $v$. Hewitt notably articulating this view. ${ }^{53}$

The Hewitt case from Illinois established the minority approach that does not enforce cohabitation contracts. In Hewitt, Victoria and Robert Hewitt cohabitated as students in college. ${ }^{54}$ After moving to Illinois, Robert worked in the medical field while Victoria cared for their children full-time. ${ }^{55}$ Victoria also assisted Robert in building his medical practice, using her skills and her parents' financial assistance. ${ }^{56}$ After 15 years of cohabitation, the couple separated and Victoria filed for divorce. ${ }^{57}$ The court dismissed the divorce action and held that Victoria was not entitled to any remedies, ${ }^{58}$ reasoning that giving her rights would devalue the institution of marriage ${ }^{59}$ and would essentially revive common law marriage, a doctrine that Illinois abolished in 1905.60

Ultimately, Victoria could not recover her contributions to the relationship despite its similarity to marriage. ${ }^{61}$ Given the Hewitt court's reasoning, a cohabitant could benefit from the other's contributions and leave the relationship with the accumulated wealth.

50. Id.

51. Kristin A. Collins, Federalism's Fallacy: The Early Tradition of Federal Family Law and the Invention of States' Rights, 26 CARDOZO L. REV. 1761, 1764 (2005) (noting that family law is currently in the domain of the states, but historically, the federal government was not limited in this way).

52. Ann Laquer Estin \& J. Thomas Oldham, Introduction, 50 FAM. L.Q. 213, 213 (2016) ("[M]ost U.S. states do not treat unmarried cohabitation as a status, and Marvin v. Marvin remains the majority view regarding how courts should adjudicate the rights of unmarried partners when a relationship ends.").

53. Hewitt v. Hewitt, 394 N.E.2d 1204, 1211 (IIl. 1979).

54. Id. at 1205 .

55. Id.

56. Id.

57. $I d$.

58. Id. at 1205 .

59. Heweitt, 394 N.E.2d at 1211.

60. Id

61. Id. 
The Hewitt decision remains good law in Illinois. ${ }^{62}$ Illinois has denied legal protections to cohabitants in other contexts as well, including claims for loss of consortium. ${ }^{63}$ In sum, the traditional rule regarding cohabitation, which now represents the minority approach led by Illinois, is that cohabitants do not have any rights between themselves. ${ }^{64}$

In states like Illinois, where cohabitants remain largely unprotected, people have reason to hesitate before making significant investments in a nonmarital relationship. Without adequate remedies, cohabitants could face financial hardship at the end of the relationship. ${ }^{65}$ For these reasons, Hewitt has been debated and the majority approach has instead recognized contractual rights for cohabitants. ${ }^{66}$

In 2001, the American Law Institute (ALI) proposed a set of rules to standardize the states' approaches to cohabitation in the Principles of the Law of Family Dissolution: Analysis and Recommendations. ${ }^{67}$ The ALI drafters proposed that cohabitants, regardless of their gender, be treated as partners under certain circumstances. ${ }^{68}$ The ALI defined "domestic partnership" as a new legal family status and addressed its dissolution. ${ }^{69}$

62. See, e.g., Ayala v. Fox, 564 N.E.2d 920, 922 (IIl. App. Ct. 1990).

63. Medley v. Strong, 558 N.E.2d 244, 248 (IIl. App. Ct. 1990).

64. Cynthia Grant Bowman, Legal Treatment of Cohabitation in the United States, 26 LAW \& POL'Y $119,126,142$ (2004). Indeed, society generally strongly disapproved of sexual relationships outside of marriage. See, e.g., Hewitt, 394 N.E.2d at 1210 (rejecting the contract claims between unmarried cohabitants due to a public policy disfavoring "private contractual alternatives to marriage"); Schwegmann v. Schwegmann, 441 So. 2d 316, 324 (La. Ct. App. 1983) (noting Louisiana's interest in discouraging "relationships which serve to erode the cornerstone of society, i.e., the family").

65. Margaret Ryznar, All's Fair in Love and War: But What About in Divorce? The Fairness of Property Division in American and English Big Money Divorce Cases, 86 N.D. L. REV. 115, 130-31 (2010). Furthermore, cohabitation may discourage marriage because a divorce likely would mean a loss of property by the higher income spouse. See, e.g., id.

66. See, e.g., J. Thomas Oldham, Lessons from Jerry Hall v. Mick Jagger Regarding U.S. Regulation of Heterosexual Cohabitants or, Can't Get No Satisfaction, 76 NOTRE DAME L. REV. 1409, 1433 (2001) ("I have proposed that the current United States approach should be changed, at least for those cohabitation relationships of some duration where a partner has suffered career damage due to the relationship, either by being a primary caretaker for a common child or for some other reason.").

67. See generally AM. L. INST., Principles of the Law of Family Dissolution $\$ 6.03$ (2002); see also Lynn D. Wardle, Deconstructing Family: A Critique of the American Law Institute's "Domestic Partners" Proposal, 2001 BYU L. REv. 1189, 1192 (2001).

68. Oldham, supra note 66 , at 1420.

69. Wardle, supra note 67 , at 1195. 
The ALI proposal moved away from Marvin's implied and explicit contract approach, instead establishing a series of factors to determine whether two cohabitants were domestic partners. ${ }^{70}$ If so, remedies would apply to their separation. ${ }^{71}$ When cohabitants wanted to opt out of the commitment, they would do so by written agreement. ${ }^{72}$ However, the ALI was not persuasive with the states, which retain the Marvin/Hewitt dichotomy and focus on contractual rights for cohabitants as the main remedy. ${ }^{73}$

\section{B. Recent Developments on Cohabitation}

While much of the cohabitation legal framework dates back to the $1970 \mathrm{~s}$, there have been several cases in recent years addressing cohabitants' rights in the United States. First, the Illinois Supreme Court declined an opportunity to overturn Hewitt and start enforcing property rights between cohabitants. ${ }^{74} \mathrm{~A}$ second development was a New Jersey legislative change that became effective in 2010, requiring cohabitation agreements to be in writing and prompting several cases. ${ }^{75}$ Third, a court in Hawaii had a case of first impression on whether premarital contributions are considered in dividing a marital estate. ${ }^{76}$ Finally, Vermont expressed the need to formulate more flexible remedies in acknowledgement of the rise of cohabitation. ${ }^{77}$ These are some of the recent major developments on cohabitation, with most of the remaining states maintaining the status quo or offering clarification on previous holdings. ${ }^{78}$

70. AM. L. INST., supra note $67, \S 6.03$.

71. Id

72. Shahar Lifshitz, Married Against Their Will? Toward a Pluralist Regulation of Spousal Relationships, 66 WASH. \& LEE L. REV. 1565, 1583 (2009).

73. Oldham, supra note 66 , at $1423,1425$.

74. Blumenthal v. Brewer, 69 N.E.3d 834, 860 (Ill. 2016); see also infra Part I.B.

75. Susan K. Livio, Palimony Claims Only Enforceable with Written Agreement Under New Law Signed by Gov. Corzine, NJ.COM (Jan. 19, 2010), https://www.nj.com/news/index.ssf/2010/01/gov_corzine_signs_bill_that_ch.html [https://perma.cc/Q9PN-DQR8]

76. Collins v. Wassell, 323 P.3d 1216, 1225 (Haw. 2014).

77. Wynkoop v. Stratthaus, 136 A.3d 1180, 1194 (Vt. 2016).

78. Bowman, supra note 64 , at 126. 
Most notably in the last few years, a challenge to Hewitt arose in Illinois in 2015. In Blumenthal v. Brewer, the Illinois Court of Appeals held that a woman could bring claims against her former partner for property they owned together. ${ }^{79}$ The Illinois Supreme Court did not uphold this decision. ${ }^{80}$

In Brewer, Jane Blumenthal and Eileen Brewer became same-sex domestic partners in the early $1980 \mathrm{~s}^{81}$ Despite the absence of samesex marriage in Illinois, the couple exchanged rings and presented themselves as a committed lifelong couple. ${ }^{82}$

For almost three decades, Blumenthal and Brewer built a life together, combined their finances, and raised three children. ${ }^{83}$ While Blumenthal focused on providing financial support for the family, Brewer spent a substantial amount of time caring for their children and home. ${ }^{84}$ After the relationship ended, Blumenthal sought partition of the property she owned with Brewer during their relationship. ${ }^{85}$ Brewer counterclaimed for various common law remedies, including sole title to the home and an interest in Blumenthal's ownership share in a medical group. ${ }^{86}$ The counterclaim aimed for the couple's overall assets to be equalized at the end of the cohabitation. ${ }^{87}$ The Illinois Court of Appeals held that the state's "public policy of prohibiting unmarried domestic partners from bringing common-law claims against one another no longer exists" and that Brewer may continue with her claims regarding the property they acquired during the relationship. ${ }^{88}$

The Illinois Supreme Court heard the appeal, but declined to overrule Hewitt. The court determined that cohabitants cannot bring

79. Blumenthal v. Brewer, 24 N.E.3d 168, 183 (Ill. App. Ct. 2014).

80. Blumenthal v. Brewer, 69 N.E.3d 834, 860 (Ill. 2016).

81. Id. at 840 .

82. Id. at 852 .

83. Id.

84. Id.

85. Id. at 839 .

86. Blumenthal, 69 N.E.3d at 839 .

87. Id.

88. Id. at 840 . 
property claims, ${ }^{89}$ noting that any changes to this approach should come from the state legislature. ${ }^{90}$

In sum, the Illinois Supreme Court refused to overrule Hewitt when provided the opportunity in recent years, denying cohabitants contract and property rights. This decision illustrates the continued lack of legal developments on cohabitation in the United States despite demographic shifts toward cohabitation. ${ }^{91}$ However, Obergefell $v$. Hodges may have mooted a major reason for cohabitant protection, which was to protect same-sex couples unable to marry. ${ }^{92}$ Nonetheless, other reasons remain for cohabitation contracts, such as protecting the vulnerable cohabitant.

Meanwhile, a legislative change prompted new case law in New Jersey. In January 2010, the New Jersey legislature amended the palimony statute governing support claims between separated cohabitants to require written agreements. ${ }^{93}$ Following this change, separated cohabitants brought two noteworthy cases. In the first case in 2014, the court determined that New Jersey Statutes $\S 25: 1-5$ did not apply retroactively to oral palimony agreements made prior to January $2010 .{ }^{94}$ Additionally, the court stated that this statutory change superseded the holdings in In re Estate of Roccamonte and Kozlowski v. Kozlowski, both of which upheld oral cohabitant agreements. ${ }^{95}$ Subsequently, in the unpublished federal case of Sook Hee Lee v. Kim, the appellant made a $\S 1983$ claim challenging the validity of the New Jersey statute. ${ }^{96}$ However, this challenge failed and was dismissed due to the appellant's failure to state a claim for violation of her First Amendment privacy rights, her Fourteenth Amendment equal protection rights, or her Fourteenth Amendment privacy rights relating to familial matters. ${ }^{97}$

\footnotetext{
89. Id. at 859 .

90. $1 d$. at 858 .

91. See id. at 853 .

92. Obergefell v. Hodges, 135 S. Ct. 2584, 2642 (2015).

93. N.J. STAT. ANN. \& 25:1-5 (2010).

94. Maeker v. Ross, 99 A.3d 795, 805 (N.J. 2014).

95. Id; see also In re Estate of Roccamonte, 808 A.2d 838, 843 (N.J. 2002); Kozlowski v. Kozlowski, 403 A.2d 902, 906 (N.J. 1979).

96. Lee v. Kim, 654 F. App'x 64, 66 (3d Cir. 2016).

97. Id at 69 .
} 
Many other cases on cohabitation in recent years focused on the contractual nature of cohabitation. ${ }^{98}$ Indeed, some courts distinguish property divisions based on cohabitation and those based on principles regarding shared property. ${ }^{99}$ This may be a solution for some cohabitants in states that are reluctant to enforce contracts based on companionship. ${ }^{100}$

For example, in 2016, the New Hampshire Supreme Court stated that the division of property between cohabitants was not a divorcelike remedy, but rather a division of property based on equitable determination of petitioner's rights in two parcels of real property. ${ }^{101}$

In another case, the Vermont Supreme Court focused on the fact that the two parties were colessees even though they were also unmarried cohabitants. ${ }^{102}$ In this case, the court crafted a somewhat flexible remedy for the plaintiff cohabitant in the context of the parties' alleged agreement for the plaintiff to quit her job and serve as the general contractor for the construction of the couple's property while the defendant supported them both through his income. ${ }^{103}$ The court stated that there is a need for flexible remedies in equity to meet modern and more complex circumstances. ${ }^{104}$

Similarly, contract consideration was at the essence of Dooner $v$. Yuen, which involved the Minnesota palimony statute and the division of real property. ${ }^{105}$ This case addressed a woman's

98. See June Carbone \& Naomi Cahn, Nonmarriage, 76 MD. L. REV. 55, 121 (2016) ("Nonmarriage, as a new legal status, could be conceptualized as the ability to craft custom arrangements, even if they are seemingly unequal. That is, marriage is a fixed institution premised on equality with a set of clear rules, while nonmarriage implies the freedom to contract on a continuum of terms. Because the law does not impose those terms, greater autonomy is possible, but formal equality between parents is not mandated and may not be appropriate. The law can only routinize these relationships if it acknowledges the reasons parents choose non-marriage over marriage, and incorporates these differences into both financial and custody decisionmaking.").

99. See infra notes 101-10.

100. See infra notes 111-14.

101. Brooks v. Allen, 137 A.3d 404, 410 (N.H. 2016). The court previously held that until the legislature directs differently, the court would not recognize an implied contract based on homemaking services. Tapley v. Tapley, 449 A.2d 1218, 1219 (N.H. 1982).

102. Wynkoop v. Stratthaus, 136 A.3d 1180, 1187 (Vt. 2016).

103. Id. at 1190 .

104. Id. at 1188 .

105 Dooner v. Yuen, Civ. No. 16-1939 (RHK/SER), 2016 WL 6080814, at *2 (D. Minn. Oct. 17, 2016). The statute at issue was MINN. STAT. $\S 513.075$ (2017). 
counterclaim to half the proceeds from the sale of her cohabitant's real property. ${ }^{106}$ She relied on a signed, handwritten document describing the cohabitants' mutual financial plans and agreements. ${ }^{107}$ However, the court found no consideration for the contract. ${ }^{108} \mathrm{Her}$ additional claims for relief under promissory estoppel and unjust enrichment also failed. ${ }^{109}$ Unlike in other cases, the fact that the item in dispute was real property did not help her. ${ }^{110}$

Conversely, Nevada has allowed both express and implied contracts based on companionship and other factors, thus eliminating the need to base the division upon the separate laws of real property. ${ }^{111}$ In the recent unpublished case of Bumb v. Young, the Nevada Supreme Court confirmed its position that property may be divided based on express or implied agreement of support in exchange for companionship, partnership, and business and personal assistance under the state's community property by analogy doctrine. ${ }^{112}$

Alaska also allows for division based on express or implied intent. The recent case of Boulds v. Nielsen provides guidance for lower courts when determining express or implied intent regarding property division. ${ }^{113}$ In this case, the court allowed the division of a pension between two cohabitants upon dissolution of their relationship based on their intent. ${ }^{114}$

Another set of circumstances relating to cohabitation arises when the cohabitants marry and then divorce. Courts must then determine how they should divide property acquired prior to the marriage upon divorce. Two recent cases from Hawaii clarify the term "premarital

106. Id. at *1.

107. Id.

108. Id. at *2.

109. Id. at *3.

110. Dooner, 2016 WL 6080814 at *2-3.

111. Bumb v. Young, No. 63825, 2015 WL 4642594, at*1 (Nev. Aug. 4, 2015).

112. Id.

113. Boulds v. Nielsen, 323 P.3d 58, 113 (Alaska 2014).

114. Id. See also Tomal v. Anderson, Supreme Court Nos. S-16720/16760, 2018 WL 4170879, at *4 n.15 (Alaska Aug. 31, 2018) (clarifying that when considering property after the end of a domestic partnership, "the correct rule is that what the parties intended is a question of fact, and the legal significance of that intent is a question of law"). 
economic partnership." 115 First, in Collins v. Wassell, as a matter of first impression, the court held that premarital contributions are to be considered when dividing the marital estate. ${ }^{116}$ Further clarification came from Hamilton v. Hamilton, where the court discussed the factors to be considered in determining whether the parties intended to form a premarital economic partnership. ${ }^{117}$ These considerations include joint acts of a financial nature, duration of cohabitation, whether and the extent to which finances are commingled, and economic and noneconomic contributions to the household for the couple's mutual benefit. ${ }^{118}$

New Jersey also recently heard a case regarding cohabitants who later married and divorced. In Thieme v. Aucoin-Thieme, the parties sought determination of whether a wife was entitled to a portion of a husband's work bonus in the divorce. ${ }^{119}$ The court determined that the wife was entitled to equitable distribution of the portion of the bonus earned during their fourteen-month marriage, but not the portion of the bonus that was earned during their eight-year cohabitation. ${ }^{120}$ However, the court held that under the theory of unjust enrichment, the wife was able to recover a portion of the bonus that was earned during their cohabitation period. ${ }^{121}$

The federal income tax code continues to inadvertently encourage cohabitation in some circumstances. This is due to the marriage penalty resulting from some income tax brackets that do not double upon marriage and phase-outs of certain tax benefits whose thresholds are not double those of single filers. ${ }^{122}$ One study has shown that if they married, more cohabiting couples would be penalized by the marriage penalty in tax law than would receive the

115. Hamilton v. Hamilton, 378 P.3d 901, 915 (Haw. 2016); Collins v. Wassell, 323 P.3d 1216, 1218 n.1 (Haw. 2014).

116. Collins, 323 P.3d at 1226.

117. Hamilton, 378 P.3d at 915.

118. Id.

119. Thieme v. Aucoin-Thieme, 151 A.3d 545, 548 (N.J. 2016).

120. Id. at 556 .

121. Id. at 559 .

122. See, e.g., Christine D. Allie, Negating the Cost of "I Do": Ending the United States Tax Code's Family Penalty Through Permissive Joint Filing, 78 LA. L. REV. 499, 506 (2018). 
marriage bonus. ${ }^{123}$ Republicans and Democrats both recognize the problem with the marriage penalty, ${ }^{124}$ but it has persisted because of the elusiveness of comprehensive solutions. ${ }^{125}$

In sum, cohabitation continues to be separate and legally distinct from marriage in the United States. In cohabitation, there are fewer rights and obligations than in marriage. ${ }^{126}$ Cohabitants' contract rights are the primary way to protect cohabitants. Among the states that recognize cohabitation contracts, there are variations regarding whether the contract must be written or oral, as well as express or implied.

123. Emily Y. Lin \& Patricia K. Tong, Marriage and Taxes: What Can We Learn from Tax Returns Filed by Cohabiting Couples?, 65 NAT'L TAX J. 807, 809 (2012) (noting that "48 percent of cohabiting couples... would have a tax increase if they were married and filed jointly"); see also Mitchell L. Engler \& Edward D. Stein, Not Too Separate or Unequal: Marriage Penalty Relief After Obergefell, 91 WASH. L. REV. 1073, 1075 (2016) ("While same-sex couples may now marry throughout the United States, the joint return system imposes a significant cost on many of them. As a result, some such couples may decide to cohabitate in lieu of marriage or to opt for a civil union, domestic partnership, or other marriage-like relationship. This is because many same-sex couples are relatively even earners.").

124. Fa'Asamala v. Comm'r, No. 9220-97 (T.C. filed Apr. 9, 1998) ("Additionally, petitioners' concern about the 'marriage penalty' is currently a matter which is being considered by members of Congress.") (citing Marriage Tax Elimination Act, H.R. 2456, 105th Cong. $\$ 2$ (1997); Marriage Penalty Relief Act, H.R. 2593, 105 th Cong. $\$ 2$ (1997)); see also Calmes v. U.S., 926 F. Supp. 582,593 (N.D. Tex. 1996) ("The Court believes that this is a classic example of the right hand not knowing (or caring) what the left hand is doing. The President and Congress extol the virtues of marriage and the family, debate per-child tax credits and laud the demise of the marriage-penalty present in the tax code, while the agency itself attempts to have its Texas community property cake and eat it too."); Lawrence Zelenak, Doing Something About Marriage Penalties: A Guide for the Perplexed, 54 TAX L. REV. 1, 1-2 (2000) (noting that although proposed bills in the late 1990 s and early 2000 s offered such relief, the President them for different reasons).

125. Lawrence Zelenak, For Better and Worse: The Differing Income Tax Treatments of Marriage at Different Income Levels, 93 N.C. L. REV. 783, 784 (2015) ("As a matter of simple arithmetic, it is impossible for a tax system to feature simultaneously (1) progressive marginal tax rates, (2) joint filing by married couples (in the service of producing equal taxes on equal-income married couples), and (3) marriage neutrality (that is, no tax marriage penalties or bonuses). If the legislature insists on the first two features, as Congress has for many decades, then the third desideratum is unachievable.... Although a legislature committed to the first two goals must violate marriage neutrality, the legislature has a great deal of freedom to determine whether, and to what extent, to skew the neutrality violations toward either marriage penalties or marriage bonuses."). Id. at 792 ("When cohabitation was not a socially available counterfactual to marriage, neither marriage penalties nor bonuses were likely to have much visceral impact.").

126. See, e.g., Courtney G. Joslin, The Gay Rights Canon and the Right to Nonmarriage, 97 B.U. L. REV. 425, 429-30 (2017) ("Regardless of how long they have been living together or how financially independent they are, unmarried partners typically cannot sue for wrongful death. Unmarried partners are not entitled to spousal social security benefits in the event of the disability of one of them. Individuals who are in mutually dependent but unmarried relationships are not entitled to take leave under the Family and Medical Leave Act to care for each other. In many states, an unmarried partner who agrees to have a child through assisted reproduction is a legal stranger to the resulting child."). 
Courts appear to be deferring to state legislatures for further guidance. As cohabitation increases, however, some courts may be expanding cohabitants' rights by focusing on existing real property laws or equitable principles.

\section{Cohabitation Developments in Poland}

Cohabitation remains outside the scope of Poland's family and guardianship code, ${ }^{127}$ although it is a form of family for many people, especially when it spans several years and produces children. Although, Polish legislation does not recognize cohabitation, it is legal. ${ }^{128}$ Some scholars have argued for the recognition of cohabitation and for the regulation of at least some of its aspects. ${ }^{129}$

Without legislative regulation on cohabitation, the key guidance for cohabitants is judicial. ${ }^{130}$ Different legal approaches are used when a cohabitation ends and there is a property dispute. ${ }^{131}$ The definition of cohabitation is controversial, and it is not clear whether it includes same-sex couples, ${ }^{132}$ although recently it has included both same- and opposite-sex couples. ${ }^{133}$

At the beginning of the relationship, cohabitants seldom consider issues related to property. ${ }^{134}$ Only the most proactive cohabitants attempt to govern their property relationship by entering into an agreement, which becomes important when the cohabitation ends and

127. See Anna Stępień-Sporek et al., Some Remarks on Cohabitation in Poland, THE INT'L SURV. OF FAM. L. 247, 251 (2015).

128. Id. at 247.

129. Mirosław Nazar, Cywilnoprawne Zagadnienia Konkubinatu de lege Ferenda, 12 PAŃSTwO I PRAWO 103, 103-13 (1989).

130. Id.

131. Seweryn Szer, Konkubinat, 13 STUDIA CYWILISTYCZNE 358 (1969).

132. Brunon Paul, Koncepcja Rozliczeń Mająikowych Między Konkubentami, 3 PRzEGLAD SADOWY 16 (2003) [hereinafter Koncepcja]; see also Marek Stus, Instytucjonalizacja Zwiqzków Partnerskich $i$ Malzeństw Homoseksualnych w Ustanvodawstwie Państw Europejskich, 5 PAŃsTwO 1 PRAwO 74 (2005); Boleslaw Banaszkiewicz, Problem Konstytucjonalnej Oceny Instytucjonalizacji Zwiqzków Homoseksualnych, 2 KWARTALNIK PRAWA PRYWATNEGO 359 (2004).

133. Filip Hartwich, Konkubinat-Dylematy Prawne, 3-4 PALESTRA 57, 57-71 (2007).

134. See generally Sean Hannon Williams, Sticky Expectations: Responses to Persistent OverOptimism in Marriage, Employment Contracts, and Credit Card Use, 84 NOTRE DAME L. REV. 733, $757-61(2009)$ 
the property acquired during the relationship becomes the subject of dispute. ${ }^{135}$

Indeed, in the context of cohabitation, the decision to acquire property is often accompanied by emotion instead of logic. Although this is similar to married couples, the law of community property-the default marital property system in Poland-protects the rights of spouses if they avail themselves of it. ${ }^{136}$ It is wellestablished, however, that these rules for married couples do not apply to cohabitants because cohabitation is not analogous to marriage, as confirmed in the resolution of the Polish Supreme Court of July 2, 1955 (case no. II CO 7/ 55). ${ }^{137}$ The rules on community property between spouses should therefore not be used for cohabitants. ${ }^{138}$ Instead, the judge hearing the cohabitants' case must apply general principles of law. ${ }^{139}$

Nonetheless, it is not possible to completely ignore the nature of the union of cohabitants. Their intimate relationship affects their decisions to some extent, and their behavior can be very close to marital. These are some of the justifications for the legal protection of cohabitants, especially for the more vulnerable party of the relationship. ${ }^{140}$ Indeed, there have been several legal protections applied to cohabitants in recent years. ${ }^{141}$

135. Id

136. If spouses have entered into a marital property agreement, their situation may not differ from cohabitants, but then they need to make a deliberate choice and consider their decision. See Margaret Ryznar \& Anna Stepien-Sporek, To Have and to Hold, for Richer or Richer: Premarital Agreements in the Comparative Context, 13 CHAP. L. REV. 27, 53 (2009).

137. See also, e.g., Sądu Najwyzzzego [Supreme Court of Poland], June 27, 1996, III CZP 70/96 (OSNC 1996/11/145, LEX nr 25824); Sądu Najwyższego [Supreme Court of Poland], May 16, 2000, IV CKN 32/00 (OSN 2000/12/222, LEX nr 43414).

138. Sądu Apelacyjnego w Krakowie [Court of Appeals in Kraków], April 29, 2014, I ACa 527/13 (LEX nr 1602935).

139. See infra Part II.

140. Emily Sherwin, Love, Money, and Justice: Restitution Between Cohabitants, 77 U. CoLO. L. REV. 711, 720 (2006) (noting a few jurisdictions that protect cohabitants in relationships similar to marriage).

141. See infra Part II. 


\section{A. The Nature of the Legal Actions of Cohabitants}

In addition to the emotional factor in property transfers between cohabitants, many of these transfers are made informally and without consideration of whether the property is common property or separate property. ${ }^{142}$ Yet, the classification of property becomes essential at the end of the cohabitation or in the event of a conflict between the cohabitants.

The constructive element of the legal action is the intent of the party. ${ }^{143}$ In settling property disputes between cohabitants, it is necessary to separate acts of kindness from those that have legal consequences. ${ }^{144}$ In practice, this is extremely difficult, and the context of the action should be examined, as it may not be detached from the particular emotional situation that arises between cohabitants.

A kind act done by one cohabitant for the other prevents the application of the unjust enrichment doctrine. ${ }^{145}$ As a consequence, there is no obligation to return such a donation. ${ }^{146}$ Many actions during a cohabitation should be treated as kind acts because the intent of the party was steered toward gratuitous actions at the time.

A cohabitation in itself does not prevent the existence of a contractual relationship between the cohabitants. ${ }^{147}$ Similarly, marital status does not affect the capacity of the spouses to enter into contracts between themselves, including civil partnerships and contractual transfers of property. ${ }^{148}$ This does not mean, however, that cohabitation contracts can be viewed in the same way as contracts between unrelated individuals. However, if the court establishes that the cohabitants have entered into a contract, the rules of that contract should apply. Therefore, the first step of the court

142. Brunon Paul, Problemy Rozliczeń Majątkowych Między Konkubentami, 8 MONTTOR PRAWNICZY 357 (2002) [hereinafter Problemy].

143. Id.

144. Id. at 357 .

145. Id.

146. Id.

147. Id. at 357

148. Problemy, supra note 142 , at 358. 
should be to examine whether there are any contracts between the cohabitants.

Economic and legal interests should be taken into account when considering the actions of cohabitants. Homemaking is an exampleas a general rule, such duties are fulfilled according to mutual agreements, are free of charge, and neither partner claims payment. This changes at the end of a cohabitation, when one partner may make claims for compensation. Still, the determinative factor is the intent of the cohabitants.

\section{B. The Legal Classification of Actions Performed Between Cohabitants}

Legal acts by cohabitants for each other can be classified as donations, ${ }^{149}$ justified by the fact that there are emotional bonds between them that make them willing to perform activities free of charge. ${ }^{150}$ However, such categorizations should not be abused because even in marital relationships, not all legal acts between spouses are of a gratuitous nature. ${ }^{151}$ For example, in the division of common property upon the termination of a marriage, one spouse can successfully seek remuneration for work done in the other spouse's business. ${ }^{152}$

When classifying the actions of cohabitants, it is important to consider the moment of their completion, which usually results in the recognition that a donation took place. Admittedly, after many years, cohabitants may be inclined to claim that their actions were of a different character than a donation, but the court should be cautious. Furthermore, the court cannot ignore the changes in the moral assessment of both cohabitation and the relevant property transfers in the last few decades. ${ }^{153}$

149. Szer, supra note 131 , at 360.

150. Id.

151. Id.

152. Id.

153. Compare the remarks made in 1969 by Seweryn Szer in Szer, supra note 131, at 361-62. 
A possible solution is to revoke the donation due to the "blatant ingratitude of the beneficiary." 154 However, it is necessary to remember the time limit for revoking a donation in Art. $899 \S 3$ of the Civil Code. ${ }^{155}$ Also, it is important to consider the meaning of blatant ingratitude. ${ }^{156}$ The termination of a cohabitation is not necessarily considered blatant ingratitude because a characteristic of cohabitation is that either cohabitant can terminate it at any time for no particular reason. ${ }^{157}$

The extent to which society's moral norms must be violated to constitute blatant ingratitude of the beneficiary is difficult to determine in a general way. ${ }^{158}$ It should be noted that even in marriage:

... [V]iolation of marital obligations referred to in Art. 23 k.r.o., i.e. mutual assistance and fidelity, and cooperation for the good of the family, which spouses have established, cannot be the basis for revoking of donation. It is important for the beneficiary to commit a gross ingratitude to the spouse, which is the subject of a court investigation, taking into account the circumstances of the case. ${ }^{159}$

Thus, blatant ingratitude cannot just be the termination of the cohabitation. It must be something more, such as ending the relationship in a very difficult time for the cohabitant like during an illness. If the criteria were easier, then the revocation of a donation could be a sanction for ending the cohabitation. ${ }^{160}$

\footnotetext{
154. KODEKS CYWILNY (CIVIL CODE), Art. 898, $§ 1$ ("A donor may revoke a donation even if already made if the donee manifests gross ingratitude towards him.").

155. Id. at Art. 899, $\S 3$ ("A donation cannot be revoked after one year has passed from the day on which the person entitled to revoke it learns of the donee's ingratitude.").

156. ANDRZEJ SZLEZZAK, STOSUNKI MAJATKOWE MiĘDZY KONKUBENTAMI: ZaGADNiENIA WYBRANE 57 (1992).

157. Id.

158. See Appeal Court Łódź, Oct. 25, 2016, 1 Aca 485/16, LEX No. 2200342 (Pol.).

159. Id.

160. SZLEZAK, supra note 156, at 57.
} 


\section{Partnership}

The provisions on civil partnership, which is characterized by a lack of formalism, may be helpful in settling cohabitants' legal actions. ${ }^{161}$ These provisions can be applied to implicit contracts between cohabitants, ${ }^{162}$ although the starting point would have to be that the cohabitants entered into this type of contract. ${ }^{163}$ If it is not possible to assume that there was a contract between cohabitants, then the other rules regarding civil partnership might be applicable. If it is possible to apply the provisions regarding civil partnership to cohabitants, one can settle contributions by the services and property of the partners.

However, the entire regulation on civil partnership cannot be applied to cohabitation. ${ }^{164}$ Although it is possible to pursue a common economic goal, it is usually the personal relationship of the cohabitants that is most significant. Regarding cohabitants, as in the case of spouses, there are no objections to the joint implementation of certain undertakings. In this case, recourse to the provisions on the civil law partnership is justified. However, the application of the civil partnership regulation cannot go too far, and it is indispensable in that case to distinguish property relations that are similar to relationships in civil partnerships. Other relationships remain outside of these rules.

\section{Unjust Enrichment}

Many courts use the provisions on unjust enrichment, namely the regulation on undue performance, to settle the cohabitants' disputes regarding property. ${ }^{165}$ Unjust enrichment can apply, for example, in

161. Tomasz Jasiakiewicz, Rozliczenia Majqtkowe Pomiędzy Osobami tej Samej ptci Pozostajacymi w Zwiazku Faktycznym i Prowadzq̨ymi Wspólnie Dziatalność Gospodarczą, 2 GlosA 122, 122-27 (2010).

162. Problemy, supra note 142, at 359.

163. See Koncepcja, supra note 132, at 24-27.

164. Problemy, supra note 142, at 359.

165. Andrzej Szlezak, Cohabitation Without Marriage in Poland, 5 INT'L J. OF LAW, POLICY \& THE FAMILY 1, 8-9 (1991). 
cases of services provided in a common household. ${ }^{166}$ However, this is controversial and should be used as a last resort. ${ }^{167}$

Cohabitants provide services for various reasons resulting from their special relationship, including a belief that they are obliged to pay maintenance or that it will guarantee a long-lasting relationship, which is the most common situation and the simplest to prove. The causal conditions of causa data causa non secuta are fulfilled because the purpose of the union cannot be attained.

The advantage to relying on unjust enrichment is that the cohabitant can demand reimbursement for services provided. ${ }^{168}$ The drawback is that, according to Art. 411(2) of the Civil Code, the cohabitant cannot demand the return of services if the performance of the services satisfies the principles of community life. ${ }^{169}$ It is necessary to closely examine all of the circumstances of the particular case because not all benefits between cohabitants are due to the principles of social coexistence. ${ }^{170}$

\section{E. Co-ownership}

The mere existence of a cohabitation does not preclude coownership. ${ }^{171}$ A co-ownership contract can be sought by the buyers of a property with the buyers acquiring appropriate rights to the property. ${ }^{172}$

There are two relevant presumptions concerning possession: the presumption of owner-like possession in Art. 339 of the Code and the

166. Id. See also William N. Eskridge Jr., Family Law Pluralism: The Guided-Choice Regime of Menus, Default Rules, and Override Rules, 100 GEO. L.J. 1881, 1930 (2012) ("[B]y providing household services or support for a partner's career or business, the claiming partner has established an equitable basis for recovering the value of her or his services.").

167. Marek Sobczyk, Rozliczenia Między Stronami Zwiqzków Partnerskich na Podstawie Przepisów o Bezpodstawnym Wzbogaceniu, 24 KWARTALNIK PRAWA PRYWATNEGo 381, 381 (2015).

168. KODEKS CYWILNy (CIVIL CODE), Art. 405.

169. Id. at Art. 411(2) ("The return of a performance cannot be demanded . . . if the performance satisfies the principles of community life"):

170. Problemy, supra note 142, at 360.

171. Polish Supreme Court, June 27, 1996, OSNC 1996, poz. 145 (1996); see also Appeal Court in Bialystok, June 12, 2014, I Aca 601/13 (2014).

172. Handbook for Real Estate Transactions, DELOITTE 138 (2017), https://www2.deloitte.com/content/dam/Deloitte/global/Documents/Legal/dttl-legal-deloitte-legalhandbook-for-real-estate-transactions.pdf [https://perma.cc/BXX6-MLXF]. 
compliance with the law of possession in Art. 341 of the Code. ${ }^{173}$ The mere demonstration of possession by both cohabitants could trigger these presumptions and lead to the conclusion that they are co-owners of certain property. ${ }^{174}$

These presumptions are particularly important with regard to movables. The transfer of real estate can be made only in notarial deed according to Art. 158 of the Civil Code, and the notary public is obliged to ask cohabitants how they want to establish ownership of the acquired property. ${ }^{175}$

\section{F. Supplementary Claims}

In addition to the protections for property co-owners, a former cohabitant is entitled to the claims referred to in Arts. 224-31 of the Civil Code when the cohabitant was still using the property after the termination of the cohabitation. ${ }^{176}$ The earlier personal relationship of the former cohabitants does not matter for this protection.

It is also worth mentioning the possibility of using the protection provided by Art. $231 \S 1$ of the Civil Code, which often applies when one of the cohabitants has built on the real estate of the other cohabitant. ${ }^{177}$ Court decisions have established that such claims can also be used by the person who possesses the land with its owner, with the co-possessor able to request that the ownership of the property be transferred to him or her. Indeed, it cannot be overlooked that, as a rule, a cohabitant at least implicitly has agreed to the use of the property by a cohabitant.

It is problematic in this case if the cohabitant acts in good faith. Usually, cohabitants know their financial situation. A liberal interpretation of the doctrine assumes that if the owner of the property did not provide the grounds for accepting that the co-owner of the property is the owner, then the co-owner should be regarded as acting in bad faith. According to this reasoning, good faith is

\footnotetext{
173. KODEKS CYWILNY (CIVIL CODE), Arts. 339, 341.

174. Szlezak, supra note 165 , at 9 .

175. KODEKS CYWILNY (CIVIL CODE), Art. 158.

176. Id at Arts. 224-31.

177. Id. at Art. $231 \S 1$.
} 
attributed to a cohabitant when the owner of the property creates a situation in which it might appear that the partner has a legal right to act.

In this doctrine, there is also a view referring to the principles of social coexistence, in which the possessor, in bad faith, should be treated as a holder who is formally in good faith. It is important, at this point, to thoroughly investigate the circumstances of the case and whether there is a particular degree of trust between the parties to the relationship which may justify a departure from the need to meet the formal requirements of good faith.

\section{G. Torts}

An injury to a partner's property or shared property will result in liability for tort damages if the injury meets the general elements of a tort. ${ }^{178}$ However, liability is excluded for certain damages caused by a cohabitant's negligence. ${ }^{179}$ This is justified by the fact that those living in a common household should be aware of certain unfavorable changes in their property resulting from the mistakes and actions of their partners.

The separation of cohabitants does not give rise to liability for damages. ${ }^{180}$ The essence of a cohabitation is that it can be ended at any time, so even a unilateral decision to leave this relationship cannot be regarded as contrary to the principles of social coexistence.

\section{H. Burden of Proof}

Important in settling disputes between cohabitants may be proving certain circumstances. ${ }^{181}$ However, legal actions do not always proceed according to proper form given the personal relationship between the cohabitants. In this context, the question is whether the

\footnotetext{
178. Id. at Art. 415.

179. Id. at Art. 440.

180. Problemy, supra note 142 , at 361 .

181. USTAWA Z DNIA 17 LISTOPADA 1964 R. KODEKS POSTĘPOWANIA CYWILNEGO [CIVIL PROCEDURE CODE], tit. 7 , ch. 2 , art. 441 , translated at https://www.globalregulation.com/translation/poland/7049655/act-of-17-november-1964\%252c-the-code-of-civilprocedure.html [https://perma.cc/YY4M-J5Y2]
} 
evidence of the witnesses or the hearings of the parties is admissible as the only means of evidence available in such cases. ${ }^{182}$ The Civil Procedure Code may, in principle, prevent certain circumstances from being demonstrated. ${ }^{183}$

\section{Limitation Period for Claims}

Limitation periods are not unique to cohabitants, although their relationship may be similar to that of spouses. ${ }^{184}$ With regard to the latter, the limitation period does not begin for the duration of the marriage. ${ }^{185}$ This is due to the existence of a special, personal relationship between the spouses and, in the course of the spousal cohabitation, it is possible to refrain from seeking redress. Similarities between cohabitation and marriage could lead to the application of provisions limiting the limitation period to cohabitation by analogy. Nonetheless, these two relationships are fundamentally different, and the case law does not extend the rules of settlement between spouses to cohabitants. ${ }^{186}$

In disputes between cohabitants, protection can be justified on the basis of the institution of abuse of rights. If the claimant has lodged a claim after the expiration of the limitation period, the limitation of the claim may be assessed in the context of compliance with the principles of social coexistence. ${ }^{187}$ Another possible solution in this case is to argue that the claims of the cohabitants become due or that the time of the dissolution of the relationship may be the earliest time to investigate. From this point on, the limitation period should start its course. However, this position is not enough to justify de lege lata. ${ }^{188}$

182. KODEKS CYWILNY (CIVIL CODE), Art. 74, § 1; Arts. 246-47.

183. USTAWA $z$ DNIA 17 LISTOPADA 1964 R. KODEKS POSTĘPOWANIA CYWILNEGO [CODE OF CIVIL PROCEDURE], tit. 7, ch. 2, art. 441.

184. Koncepcja, supra note 132 , at 40.

185. KoDEKS CYWLNy (CIVIL CODE), Art. 121, 33.

186. The resolution of the Supreme Court of $8^{\text {th }}$ August 1986, III CZP 45/86, OSNC 1987, position 95.

187. See supra text accompanying note 170 .

188. Miroszaw NAZAR, RozliCZENIA MAJĄTKOWE KonkUBENTów 200 (1993); SZLĘZAK, supra note 156 , at 72 . 


\section{A Comparative Analysis}

The legal developments on cohabitation in the United States and Poland have slowed in recent years. ${ }^{189}$ In the United States, the Hewitt case from Illinois established the minority approach of American courts to cohabitation, which is to not enforce cohabitation contracts on public policy grounds. ${ }^{190}$ In 2016, the Illinois Supreme Court declined to overrule Hewitt despite the opportunity to do so. ${ }^{191}$ Although there have been several additional cohabitation cases in recent years across the country, major doctrinal strides have been limited. ${ }^{192}$

In Poland, there are new court decisions regarding cohabitation, but they are similarly limited. ${ }^{193}$ Indeed, the question remains among Polish lawmakers and judges whether a legal response to this social phenomenon is necessary. Although the number of cohabitations is increasing, the pro-family policy of the law continues to aim to protect marriage as a basic structure of family. The demographic trends on cohabitation in Poland, however, are similar to those in other European countries and the United States in that they are increasing. ${ }^{194}$

Cohabitation contracts setting the terms of a separation remain the primary way that cohabitants can protect themselves. ${ }^{195}$ However,

189. This has not historically been true. As illustrated by the development of the United States law on cohabitation (and, in particular, on contract enforcement between cohabitants), there have been spurts of legal development on the topic. See supra Part l. As Professor Mary Ann Glendon wrote in 1989, many countries had "a progressive withdrawal of official regulation of marriage formation, dissolution, and the conduct of family life" and "increased regulation of the economic and child-related consequences of formal or informal cohabitation." MARY ANN GLENDON, THE TRANSFORMATION OF FAMILY LAW: STATE, LAW, AND FAMIL Y IN THE UNITED STATES AND WESTERN EUROPE 2 (1989).

190. Hewitt v. Hewitt, 394 N.E.2d 1204, 1210 (IIl. 1979).

191. Blumenthal v. Brewer, 69 N.E.3d 834, 853 (Ill. 2016); see also supra Part I.B.

192. See supra Part I.B.

193. See supra Part II.

194. See supra Introduction.

195. Marsha Garrison, Is Consent Necessary? An Evaluation of the Emerging Law of Cohabitant Obligation, 52 UCLA L. REV. 815, 815 (2005). Today still, "[i]n the United States ... unmarried cohabitants have no obligations to each other unless they have contracted to assume such obligations." Id.; see also Erez Aloni, The Puzzle of Family Law Pluralism, 39 HARV. J.L. \& GENDER 317, 317 (2016) ("As ... scrutiny of prenuptial and cohabitation agreements reveals, neoclassical contract theory is slowly taking over family law."). 
this is only an effective method if courts recognize and enforce such contracts. ${ }^{196}$ Furthermore, cohabitants must know about this option to enter into such contracts. Thus, it is important to promote the idea of contractual regulation of property relationships between cohabitants, especially if the state legislature is silent on the issues.

In both the United States and Poland, such contracts are not currently popular and instead general legal principles apply at the end of the cohabitation. ${ }^{197}$ However, this may not be the best solution because the general rules are universal and do not take into account the larger context of the behavior of cohabitants who undertake various decisions and legal actions outside of a legal framework. Furthermore, the emotional underpinning of cohabitation should play an important role in judicial determinations.

Legislators differ on what additional legal protections should extend to cohabitants. ${ }^{198}$ Trial marriages, long-term cohabitations with children, and older cohabitants with adult children from previous relationships are all different-making it difficult for legislators to craft one law to apply to them all. For example, a woman might spend a night with her boyfriend a few times per week, keeping a toothbrush and sock drawer at his apartment. Or, a woman might buy a condo with her boyfriend and share a joint bank account. Cohabitation scenarios, therefore, widely differ.

Furthermore, legislators may want to protect individual cohabitants while not encouraging the institution of cohabitation as a substitute for marriage given some of the benefits of marriage and drawbacks of cohabitation. ${ }^{199}$ One of the major drawbacks to

196. Ann Laquer Estin, Marriage and Divorce Conflicts in International Perspective, 27 DUKE J. COMP. \& INT'L L. 485, 487-88 (2017). Generally speaking, "[i]n the context of global families, the case for allowing couples to select the law that will apply to their personal and property interests seems especially strong." Id.

197. See infra Parts I \& II

198. See generally Ron Haskins \& Isabel V. Sawhill, The Decline of the American Family: Can Anything be Done to Stop the Damage?, 667 ANNALS AM. ACAD. POL. \& SoC. SCI. 8, 12 (2016).

199. Margaret F. Brinig, Adultery: Trust and Children, 95 TEX. L. REV. 611, 624 (2017) (reviewing DEBORAH L. RHODE, ADULTERY: INFIDELITY AND THE LAW (2016)).

Marriage, as opposed to cohabitation, can be characterized by its relative permanence, its unconditional love, and its status as an institution (receiving of public and private support). In addition to ... the numerous statutory benefits marriage grants, married couples gain the commitment to sexual monogamy and 
cohabitation is the very reason that vulnerable cohabitants result: cohabitations are unstable. ${ }^{200}$ Legislators may also want to defer to certain cohabitants' preferences not to be regulated. ${ }^{201}$

Courts, meanwhile, have more cases regarding cohabitants each year, but there are still not enough decisions to provide a comprehensive legal framework on cohabitation. ${ }^{202}$ In addition, courts often use general principles of law in such cases instead of addressing the narrow issues relating to cohabitation in particular, which is not always satisfactory for building consistent law. ${ }^{203}$ However, family policy is currently focused most on protecting the traditional model of family, which remains married people and their children. ${ }^{204}$ This is seen most recently in Obergefell v. Hodges, which encourages family formation through marriage. ${ }^{205}$ As a result, cohabitants must continue to wait for a more established legal response to cohabitation.

\footnotetext{
permanence of marriage that, in turn, promotes trust. It is that trust that catalyzes the many fruits of marriage because, in a word, it signifies the production of social capital.

Id.
}

200. Haskins \& Sawhill, supra note 198 , at 12 . "Nearly 40 percent of cohabiting couples who have a baby are no longer together by the time the child reaches age five, about three times the breakup rate for married couples over the same period." Id.

201. Gregg Strauss, The Positive Right to Marry, 102 VA. L. REV. 1691, 1696 (2016). "Cohabitants do not need a basic right to legal status, because once couples can create legal duties through marriage, they may choose to live together without undermining one another's liberty." Id.

202. See, e.g., Clare Huntington, Nonmarital Families and the Legal System's Institutional Failures, 50 FAM. L.Q. 247, 247 (2016) ("For all its shortcomings, family law provides an institution to help divorcing couples restructure their families following the end of relationships. For nonmarital families, not so much. Unmarried parents theoretically can go to court when they separate, but most do not. Thus, as a practical matter, the legal system leaves unmarried parents without an effective way to transition from families based on romantic relationships to families based on co-parenting.").

203. Martha A. McCarthy \& Joanna L. Radbord, Family Law for Same Sex Couples: Chart(er)ing the Course, 15 CAN. J. FAM. L. 101, 167-68 (1998).

204. Huntington, supra note 202, at 257.

205. Obergefell v. Hodges, 135 S. Ct. 2584,2600 (2015). The downside of public policy's priority of marriage is the lack of protections for vulnerable cohabitants. Melissa Murray, Essay, Obergefell v. Hodges and Nonmarriage Inequality, 104 CAL. L. REV. 1207, 1207 (2016) ("Obergefell builds the case for equal access to marriage on the premise that marriage is the most profound, dignified, and fundamental institution that individuals may enter. By comparison, alternatives to marriage, which I collectively term 'nonmarriage,' are less profound, less dignified, and less valuable. On this account, the rationale for marriage equality rests-perhaps ironically $\longrightarrow$ on the fundamental inequality of other relationships and kinship forms."). 


\section{CONCLUSION}

This article analyzes the recent legal developments on cohabitation based on a comparative analysis, focusing on the various protections offered to cohabitants upon separation. Such developments have remained few, with contract remaining the primary method of protecting the vulnerable party leaving a cohabitation, even though many cohabitants do not have a contract. ${ }^{206}$ Thus, cohabitants must continue relying on themselves for protection when it comes to the property consequences at the end of their relationship.

206. Jeanne M. Hannah, The Law and Living Together, 7 L. TRENDS \& NEWS: PRAC. AREA NEwSL. $47,47(2010)$. 